Post peer review version of Maja Zehfuss, "Hierarchies of Grief and the Possibility of War: Remembering UK Fatalities in Iraq", Millennium: Journal of International Studies, vol. 38, no. 2 (2009), pp. 419-440. (ISSN 0305-8298)

\title{
Hierarchies of Grief and the Possibility of War: Remembering UK Fatalities in Iraq
}

\author{
Maja Zehfuss ${ }^{1}$
}

As I write, the number of UK military fatalities in Afghanistan - currently 184 - has overtaken the UK death toll in Iraq. The recent surge in deaths of armed forces on operation in Afghanistan has led to accusations about the inadequacy of the equipment the military is provided with and controversy over the strategy pursued in the conflict. ${ }^{2}$ Yet there has also been a different reaction: hundreds of mourners lined the streets of Wootton Bassett as the bodies of eight soldiers killed were repatriated. ${ }^{3}$ There has been speculation that the strength of the public reaction is related not only to the number of deaths, but also to the fact that some of those killed were still only teenagers. The wife of Corporal Jonathan Horne, who was 28 years of age when he was killed by a secondary explosive device during the attempt to save others, appeared on the news. Her grief at the loss of her husband was obvious. She appeared, quite simply, devastated.

Grief seems, on the face of it, to be deeply personal and private. Yet inasmuch as violence is perpetrated by and against human beings as members of communities, it becomes public. In her recent work, Judith Butler offers a critique of war that revolves around the related issues of what she calls the grievability of lives and the framing of violence. Whilst the implications for critiquing war are formulated more clearly in her latest book, Frames of War, the central idea of thinking about global violence in terms of the grievability of lives is already articulated in Precarious Life, Butler's reaction to the events of September 11, 2001 and the response to them. The thrust of her argument is to reject the view that "experiences of vulnerability and loss have to lead straightaway to violence and retribution": 4 she rather seeks to find another way forward. She argues that it is "important to ask what, politically, might be made of grief besides a cry for war." ${ }^{5}$ This is a powerful question not only because grief has been instrumentalised to justify military violence, but because views of this kind are expressed not just by governments that may perhaps be expected to rationalise their use of violence. Rather that violence begets violence, that it is no wonder that those whose loved ones have been killed will clamour for war, is a common view. Clearly, if something other than a desire for war could be made of the experience of grief, this would be significant.

This article explores aspects of the remembrance of UK military personnel killed on Operation TELIC in Iraq, drawing on Butler's powerful arguments about the way in which some lives are produced as more grievable than others. Taking my cue from Butler's observation that only one side in this war - those who live in the West - receive obituaries and that this reflects and indeed produces the frame within which violence becomes possible, I explore a particular set of obituaries from Operation TELIC: those posted by the Ministry of Defence on its website. My concern is not with the fact that some lives remain

$1 \quad$ I would like to thank Emmanuel-Pierre Guittet, Peter Lawler, Angharad Closs Stephens and Angie Wilson for their helpful suggestions on this subject and Alison Howell and Peter Lawler for their excellent comments on a draft.

2 See, for example, "PM defends Afghanistan strategy", BBC, 13 July 2009,

http://news.bbc.co.uk/1/hi/uk politics/8147679.stm.

$3 \quad$ Robert Booth, "Pride and anger over eight dead soldiers", The Guardian, 15 July 2009, p. 4.

$4 \quad$ Judith Butler, Precarious Life: The Powers of Mourning and Violence (London: Verso 2004), p.

XII.

Butler, Precarious Life, p. XII. 
unacknowledged, but rather with how the loss of lives that are acknowledged as grievable is represented. This exploration is in one sense deliberately unfaithful to Butler's argument, who does not herself examine any obituaries. Butler's concern is with public discourse and not least the way in which it may be seen to 'de-realise' certain kinds of lives, making their termination something less than killing. ${ }^{6}$ Her examples - and there are only very few concern obituaries in newspapers such as the New York Times or the San Francisco Chronicle. My focus is, in contrast, on a government-maintained website. Yet the obituaries examined here are a significant part of the production the frame that makes war possible. In Butler's scheme of grievable Western lives versus ungrievable non-Western lives no consideration is given to members of the military whose lives are grievable and yet put at risk in order, apparently, to protect other lives. Introducing this complication makes it possible to examine further how hierarchies of grief enable the possibility of war.

\section{Hierarchies of Grief}

Butler's concern is the way in which some lives appear to be grievable whereas others do not. She thinks about this around the failure to acknowledge the loss of Muslim lives in conflict in the same way as that of American lives. She asks:

Will those hundreds of thousands of Muslim lives lost in the decades of strife ever receive the equivalent to the paragraph-long obituaries in the New York Times that seek to humanize - often through nationalist and familial framing devices - those Americans who have been violently killed? ${ }^{7}$

Her suspicion is not merely that we fail to publicly mourn these lives, but more fundamentally that we fail to "conceive of Muslim and Arab lives as lives" in the first place. ${ }^{8}$ More generally, some lives are valued more than others and this can be seen in the way in which they are remembered and grieved. Whilst all lives are vulnerable and precarious, "[c]ertain lives will be highly protected, and the abrogation of their claims to sanctity will be sufficient to mobilize the forces of war. Other lives will not find such fast and furious support and will not even qualify as 'grievable'." It is a matter of "[w]hose lives are regarded as lives worth saving and defending, and whose are not". ${ }^{10}$ There is, in other words, a relationship between the grievability of lives and the sort of protection available to them.

Butler is therefore interested in "the differential allocation of grievability that decides what kind of subject is and must be grieved, and which kind of subject must not, operates to produce and maintain certain exclusionary conceptions of who is normatively human: what counts as a livable life and a grievable death". ${ }^{11}$ She asks in particular whether "a Muslim life is as valuable as legibly First World lives"12 and points out that we are rarely told the names of the Palestinians who are killed by Israeli forces or those of Afghans killed in the ongoing conflict. She asks: "Do they have names and faces, personal histories, family, favorite hobbies, slogans by which they live?"13 There is a lot at stake in this question because what is at issue is the extent to which those whose deaths are not acknowledged fall outside the Western grasp of the human. As a consequence, the ending of such lives does not register in the same way, does in fact not amount to killing. Those who are not imagined as human are not mourned in the same way: "After all, if someone is lost, and that person is not someone, then what and where is the loss, and how does mourning take place?"14 This

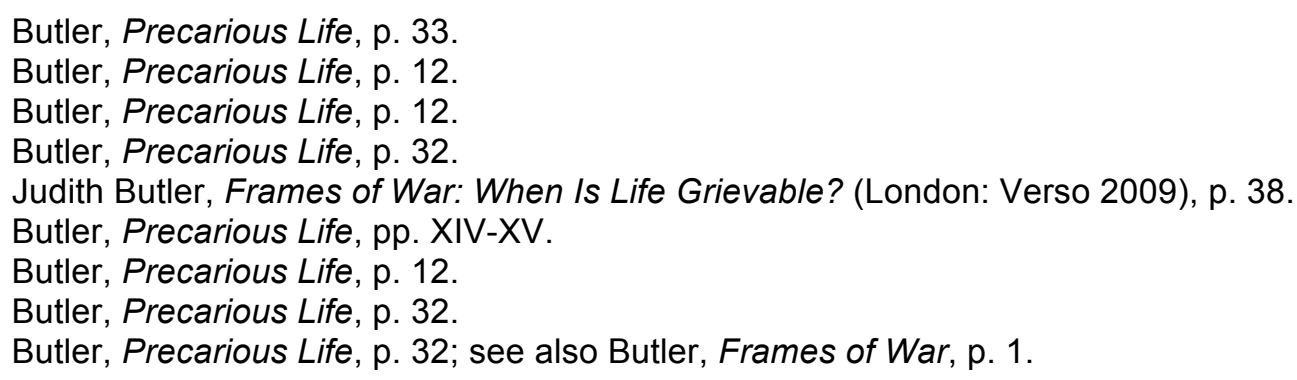


impossibility of mourning, Butler suggests, means that the lives in question are in some way considered unreal, with very real consequences: "If violence is done against those who are unreal, then, from the perspective of violence, it fails to injure or negate those lives since those lives are already negated." 15

In sum, for Butler the central question is who counts as human ${ }^{16}$ and this is inextricably linked to whose life is grievable: "grievability is a presupposition for the life that matters."17 Put differently, Butler argues that there is a "hierarchy of grief", which is visible in the "genre of the obituary, where lives are quickly tidied up and summarized, humanized". ${ }^{18}$ What is at issue in Butler's argument is not so much what obituaries do, however, as who merits one in the first place. She asserts categorically that there "are no obituaries for the war casualties that the United States inflicts, and there cannot be." 19 She acknowledges that it may be impracticable to produce such obituaries for everyone killed, but her point is obviously not about the possible practical obstacles to identifying and tracing the story of everyone killed in warfare. It is rather that such obituaries would be impossible because their existence would indicate that the lives destroyed had a claim to protection. Elsewhere, I suggested that things are more complicated. Whilst there may never have been any obituaries in the New York Times or other newspapers in the United States, ${ }^{20}$ Iraq Body Count does produce memorials to the civilian victims of violence in Iraq. ${ }^{21}$ Moreover, the claim that there are no obituaries for those killed by the United States, that 'we' do not mourn them, can only be made from within an American (or at least Western) frame. Whilst Butler asserts categorically that there are no obituaries for those killed by the US armed forces, it is not likely that she doubts that Iraqis, Palestinians or Afghans grieve for their dead. Therefore, although presented as a general truth, her point is about public discourse in the United States or perhaps in the West more broadly. In Frames of War Butler indeed explicitly notes the problem of offering a "first world critique". ${ }^{22}$ Yet there is nevertheless an inescapable irony in Butler's position. She chooses to speak within the frame that she critiques. ${ }^{23}$ Yet by claiming that certain lives cannot be grieved she belies the point: her own argument acknowledges these lives as lives and therefore as grievable.

Butler's argument is significant, however, and it is worth going further in thinking with her on this issue. Even though Iraq Body Count and other groups try to bring the human misery occasioned in particular but not only by civilians deaths to the attention of Western publics, arguably these deaths do not occupy the same space in public discourse. Most of us would struggle to name many of the Iraqi dead, though some names have become familiar. Those of us living in the UK will recall Baha Mousa, for example, whose death in the custody of UK forces in September 2003 led to an inquiry by Royal Military Police, a court martial and finally a public inquiry. ${ }^{24}$ Yet Butler has a point when she observes how much more familiar Daniel Pearl, the journalist kidnapped and beheaded in Pakistan in January 2002, is to her: "he could be my brother or my cousin; he is so easily humanized; he fits the frame, his name has my father's name in it. His last name contains my Yiddish name." ${ }^{25}$ She also notes "his

\footnotetext{
$15 \quad$ Butler, Precarious Life, p. 33.

$16 \quad$ Butler, Precarious Life, p. 20.

17 Butler, Frames of War, p. 14.

18 Butler, Precarious Life, p. 32.

$19 \quad$ Butler, Precarious Life, p. 34.

20 Butler also uses the example of obituaries for two Palestinian families being rejected by the San Francisco Chronicle. Precarious Life, p. 35

$21 \quad$ Maja Zehfuss, "Subjectivity and Vulnerability: On the War with Iraq", International Politics, special issue on Ethics in World Politics: Cosmopolitanism and Beyond?, vol. 44, no. 1 (2007), pp. 6567.

$22 . \quad$ Butler, Frames of War, p. 93.

23 This, of course, is a precondition of the possibility for deconstruction.

24 The Baha Mousa Public Inquiry, http://www.bahamousainquiry.org/.

$25 \quad$ Butler, Precarious Life, p. 37.
} 
wife's education" that "makes her familiar, even moving" to her. ${ }^{26}$ Pearl is, Butler observes, "so much more easily humanized for most United States citizens than the nameless Afghans obliterated by United States and European violence." 27

There is an intriguing omission in her considerations, however. Butler identifies a hierarchy of grief between Western lives and non-Western lives and suggests that this reflects a hierarchy of claims to the protection of life along the same lines. Yet Butler speaks only of particular sorts of Western lives. Obviously, given the context of her argument, those who died on September 11, 2001 are central. It seems to me, however, that most Westerners killed in current military operations are quite unlike Pearl; they are military service personnel, a group of humans that Butler gives scant consideration to, even though Precarious Life was published after the invasion of Iraq and Frames of War purports to be written "in response to contemporary war". ${ }^{28}$ Whilst Butler at one point mentions "US soldiers dead and decapitated in Iraq", ${ }^{29}$ by and large in both books military service personnel figure only as perpetrators, especially of the abuses committed at Abu Ghraib. This is particularly surprising as she offers reflections on the nation-state as a source of both protection and violence. $^{30}$ The armed forces are central to this arrangement, and yet Butler does not refer to them in this context.

That is, Butler does not seem to consider the intriguing position members of the armed forces occupy with respect to the differentiation of populations into those who are to be protected and those who are not. War, as Butler observes, "is precisely an effort to minimize precariousness for some and to maximize it for others." ${ }^{31}$ Whilst members of the armed forces are not the target of violence by their own nation-state, their lives are deliberately risked in the pursuit of the protection of other lives. It is therefore interesting to explore not only reactions to civilian deaths in the localities subjected to war, but also to those of military service personnel. Prima facie, it appears that their deaths are not only publicly acknowledged but mourned. That is, their lives appear to be grievable in Butler's sense there are certainly obituaries for those killed on active duty and their passing is also marked in other ways. Nevertheless, their deaths are accepted as a matter of course. If any proof was needed for this, the space left on the UK Armed Forces Memorial to enable the engraving of the names of 15,000 future fatalities is a powerful reminder that these deaths are expected. ${ }^{32}$ The armed forces, therefore, occupy an interesting space in the imaginary of highly protected Western lives versus disposable non-Western lives (or indeed, to be more faithful to Butler's conceptualisation, non-Western non-lives) ${ }^{33}$

\section{Remembering Life}

On 30 April 2009, British troops officially ended combat operations in southern Iraq. This was an opportunity for government representatives to remember and pay tribute to the 179 UK service personnel and Ministry of Defence civilians killed in Iraq. Defence Secretary John Hutton attended a service in Basra to honour the dead and the "names of the British, Italian, Dutch, Danish, American and Romanian troops and the civilian contractors killed since 2003, were read out at the memorial wall in front of the 20th Armoured Brigade

\footnotetext{
$26 \quad$ Butler, Precarious Life, p. 38.

$27 \quad$ Butler, Precarious Life, p. 37.

28 Butler, Frames of War, p. 1.

29 Butler, Precarious Life, p. 149.

$30 \quad$ Butler, Frames of War, p. 26.

$31 \quad$ Butler, Frames of War, p. 54.

32 "How the names are recorded", The National Memorial Arboretum,

http://www.thenma.org.uk/content/How-the-names-are-recorded-1405.shtml.

For the notion of 'disposable lives' see Achille Mbembe, "Necropolitics", trans. Libby Meintjes, Public Culture, vol. 15, no. 1 (2003), pp. 11-40.
} 
headquarters." 34 The formula traditional for UK remembrance ceremonies was read out: "At the going down of the sun, and in the morning, we will remember them." ${ }^{35}$ The Last Post was played and a minute's silence held.

This official commemoration was neither the first nor the only reaction to the deaths of UK service personnel. The Ministry of Defence not least maintains a website listing "British fatalities" in the operations in Iraq. At the top of this page is the following statement: "It is with very deep regret that the Ministry of Defence has confirmed the following fatalities suffered during Operation TELIC." ${ }^{36}$ The site lists all 179 UK Armed Forces personnel and MoD civilians killed on the operation; it also provides links to a page for (almost) each individual, ${ }^{37}$ though in the case of several deaths in the same incident these are sometimes amalgamated with individual information given on a joint page. The formula used by the Ministry of Defence to announce each death repeats the expression of 'deep regret' or even 'great sadness'. That is, the grief caused by these deaths is acknowledged, however perfunctorily. Often the grief caused to the family is also mentioned specifically. In other words, the deaths of military personnel are, in Butler's terminology, grievable. They are acknowledged in public discourse as lives lost. It is important, then, to examine how these lives and their loss is construed.

On a basic level the obituaries simply acknowledge every death. With very few exceptions, ${ }^{38}$ each individual killed is named, as was the case in the commemoration ceremony mentioned earlier. This naming in itself makes them more human to us than are the often nameless civilian victims; it marks out the individuality of each of the dead. They may have been killed as anonymous coalition forces, but we remember them as persons, entitled to their names. ${ }^{39}$ This appears to be the point of these obituaries: to show us that the one who died was not just a number, a holder of a rank, but a person, respected by colleagues and loved by family and friends.

The obituaries, by and large, follow a pattern. They are headed by a formulaic announcement of the death: "It is with immense sadness that the Ministry of Defence must confirm the death of Corporal John Johnston Cosby in Iraq on Sunday 16 July 2006."40 Other deaths are announced with 'deep regret', for example, but the sentiment remains the same. Normally, there is some indication as to how death occurred, for example by accident, through gunshot wounds or through the impact of an Improvised Explosive Device (IED), unless there was an investigation ongoing when the memorial was posted. We are also routinely informed as to whether or not the death was caused by enemy action. There usually follows a short biography detailing the deceased's service record but also an account

$34 \quad$ Richard Norton-Taylor and Matthew Taylor, "British troops officially end combat operation in southern Iraq", The Guardian, 30 April 2009, http://www.guardian.co.uk/world/2009/apr/30/british-troops-end-combatrole-basra.

35 "Video: British fallen remembered as Iraq operations come to end", Yorkshire Post, 30 April

2009, http://www.yorkshirepost.co.uk/video/Video-British-fallen-remembered-as.5223982.jp.

36 Ministry of Defence, "Operations in Iraq: British Fatalities", no date,

http://www.mod.uk/Defencelnternet/FactSheets/OperationsFactsheets/OperationsInIraqBritishFatalities.htm.

37 Intriguingly, there a few for whom there are no links. In some cases the link is to a page without any additional information.

38 One soldier, who died on 26 March 2008, is not named, apparently due to the family's wishes. In another incident only one of two is named. Ministry of Defence, "British solider called in Iraq on 26 March 2008", 26 March 2008,

http://www.mod.uk/Defencelnternet/DefenceNews/MilitaryOperations/BritishSoldierKilledInIraqOn26March2008.htm; Ministry of Defence, "Two UK military personnel killed in Puma helicopter crash", 21 November 2007,

http://www.mod.uk/Defencelnternet/DefenceNews/MilitaryOperations/TwoUkMilitaryPersonnelKilledlnPumaHelicopterCrash.htm

$39 \quad$ Although I make no explicit reference to Jenny Edkins's work in this piece, some of my

thoughts are influenced by discussions about her recent research on 'missing persons'.

$40 \quad$ Ministry of Defence, "Corporal John Cosby killed in Iraq", 17 July 2006,

http://www.mod.uk/Defencelnternet/DefenceNews/MilitaryOperations/CorporalJohnCosbyKilledInIraq.htm. 
of how he or she came to join the military. This often involves some assertion about what was important to them in their lives, their professional ambitions but also reference to family ties and hobbies and interests. All obituaries note marital status and often further reference is made to the family situation: children, parents, brothers, sisters, grandparents and so on. There are statements by commanding officers and colleagues as well as, usually, from the family. Often the page is concluded with a statement from the Secretary of Defence. Finally, although their grief is publicised in the online memorial, many obituaries end with a request to the media to respect the family's wish to mourn in private. There is always a picture of the deceased, sometimes with colleagues, their partner or children. Intriguingly, some pages only announce the death, without any further details; often, but not always, this involves a statement that this is done at the family's request. It should be noted that, unlike the carefully composed obituaries published in newspapers, these webpages are something of a patchwork of various statements by different people.

Corporal John Johnston Cosby's obituary contains most, though not all, of the common elements that we find in these memorials. Corporal Cosby of $1^{\text {st }}$ Battalion The Devonshire and Dorset Light Infantry died as a result of gunshot wounds received in an operation in Basra. He was from Belfast, though his family moved to Exeter when he was seven years old. He joined the military in 1998 and started his career as a rifleman in an Armoured Infantry platoon. After a tour of duty in Northern Ireland he was promoted to Lance Corporal. $\mathrm{He}$ excelled in his professional training and duties and earned promotion to full Corporal. $\mathrm{He}$ joined the Reconnaissance Platoon, "a post reserved for the top percentage of infantry soldiers, this time achieving a Distinction on his gunnery course." During the operation in Iraq he again "excelled" on a training course, became "well respected" by superiors and subordinates and showed "uncompromising professionalism". But he was also "held in great affection". The obituary here shifts in tone. After the account of Corporal Cosby's professional accomplishments, we now learn what John was like:

John was very compassionate and there was something infectious in him that people couldn't help but like: his determination, his awkward sitting style, his scruffy appearance, his inability to tan even in the desert, his honesty, his lack of sporting prowess, the constantly burning cigarette, the regular mickey-taking of himself and others, his sharp, intelligent wit, his professionalism and his generosity.

There follows a statement from Corporal Cosby's commanding officer Lieutenant Colonel Toffer Beattie that describes in more detail the events leading to his death and then goes over the same ground about his professional achievements and personal characteristics. Beattie finishes by saying: "John was unmarried. Our deepest sympathy goes out to his family, particularly his mother and sister to whom he was very close. He will be sorely missed by the Battalion and the wider Regimental family." A statement by Cosby's mother notes his "sense of humour and bubbly personality". She says his "memory will live in all our hearts forever." ${ }^{41}$

Most of the obituaries have this dual approach. On the one hand, the story of this particular life is told in an almost detached way, using the usual markers of a life: origin, education, professional achievements, family status, cause of death and so on. On the other hand, there are elements that break out of this pattern, and these I find to be the most moving. Often these pieces of information do not show the person's path through life or accomplishments. They do not show that the dead person was an accomplished soldier or a good human being. Yet they reveal the uniqueness of the person in some way. Corporal Cosby's 'awkward sitting style' was apparently something that those who knew him would recall as unique to him. Rifleman Edward Vakabua's "taste in shirts" was apparently not exactly "discreet" and those who knew him may well remember him wearing "a colourful 
Fijian 'Bule' shirt." 42 Major Robert Howieson "will always remember" Guardsman Stephen Ferguson's "approach to applying camouflage cream on exercise; each day would see him with a new cam cream moustache, from Groucho through to handlebar!"43 Such observations make no particular sense of their lives. They seem to merely say: this was him (or her). This is why these snippets feel more personal, individual, singular. As Jacques Derrida puts it, "we know that the unforgettable singularity of such moments will never be replaced by anything else, not even by that which they promise or keep in reserve. They are irreplaceable, and that is precisely the reason for despairing." 44

Yet we do not despair enough about the deaths of military service personnel to no longer risk their lives. In fact, what is striking in reading all these obituaries is that this desire to reveal the individual by and large fails. Despite the evident effort to describe each individual as just that - an individual, there is something depressingly repetitive about these pages. Invariably, there is praise for the deceased's professionalism. Lieutenant Philip West was "admired by his colleagues for his professionalism" ${ }^{45}$ and Sergeant Chris Hickey "was the epitome of the professional soldier; diligent, motivated, enthusiastic and tremendously fit." ${ }^{46}$ Many of the dead are described as rising stars, marked out for early promotion. They were an example or even inspiration to others. Apart from taking whatever their specific role was extremely seriously, they were usually marked out, or so the obituaries claim, by their physical fitness and indeed their sense of humour. Staff Sergeant Chris Muir "was the sort of person that could light up a room just by being in it. He had a fantastic sense of humour and always tried to see the funny side, no matter what the situation." ${ }^{47}$ Whilst only Second Lieutenant Jonathan Bracho-Cooke is actually described as "faultless", 48 any acknowledgement of imperfection only ever concerns memorable but ultimately unimportant shortcomings, such as "an eccentric approach to uniform" ${ }^{49}$ or "not being very good at ironing his uniform". ${ }^{\circ}$

These obituaries tell, very briefly, a story about the life lived and lost. They humanise, or at least attempt to humanise, the dead soldiers. Yet this is not easy. Obituaries celebrate the life of the deceased and hence focus on - and indeed may embellish - accomplishments and positive character traits. Many of those remembered in these memorials are represented as popular, universally liked and indeed happy. Butler talks about the "genre of the obituary, where lives are quickly tidied up and summarized, humanized, usually married,

$42 \quad$ Ministry of Defence, "Rifleman Edward Vakabua from $4^{\text {th }}$ Battalion The Rifles dies at Basra Palace on 6 July 2007", 8 July 2007,

http://www.mod.uk/Defencelnternet/DefenceNews/MilitaryOperations/RiflemanEdwardVakabuaFrom4thBattalionTheRiflesDiesA tBasraPalaceOn6July2007.htm.

43 Ministry of Defence, "Guardsman Stephen Ferguson $1^{\text {st }}$ Battalion Scots Guards dies in Selly

Oak", 14 December 2007,

http://www.mod.uk/Defencelnternet/DefenceNews/MilitaryOperations/GuardsmanStephenFerguson1stBattalionScotsGuardsDie sinSellyOak.htm.

$44 \quad$ Jacques Derrida, The Work of Mourning, ed. Pascale-Anne Brault and Michael Naas

(Chicago: University of Chicago Press 2001), p. 127.

45 Ministry of Defence, "Lieutenant Philip West, Royal Navy”, 28 May 2009,

http://www.mod.uk/Defencelnternet/DefenceNews/MilitaryOperations/LieutenantPhilipWestRoyalNavy.htm.

${ }_{46} \quad$ Ministry of Defence, "Gunner Lee Thornton dies of wounds sustained in Iraq", 9 September

2006 ,

http://www.mod.uk/Defencelnternet/DefenceNews/MilitaryOperations/GunnerLeeThorntonDiesOfWoundsSustainedlnIraq.htm.

$47 \quad$ Ministry of Defence, "Staff Sergeant Chris Muir", 28 May 2009,

http://www.mod.uk/Defencelnternet/DefenceNews/MilitaryOperations/StaffSergeantChrisMuir.htm.

${ }_{48} \quad$ Ministry of Defence, "Second Lieutenant Jonathan Carlos Bracho-Cooke killed in Iraq", 6

February 2007,

http://www.mod.uk/Defencelnternet/DefenceNews/MilitaryOperations/SecondLieutenantJonathanCarlosBrachocookeKilledInIraq $\frac{. h t m}{49}$.

$\frac{\overline{4}}{49}$. Ministry of Defence, "Major Nick Bateson killed in Road Traffic Accident in Iraq", 2 May 2007,

http://www.mod.uk/Defencelnternet/DefenceNews/MilitaryOperations/MajorNickBatesonKilledlnRoadTrafficAccidentInIraq.htm.

50 Ministry of Defence, "Rifleman Aaron Lincoln killed in Iraq", 3 April 2007,

http://www.mod.uk/Defencelnternet/DefenceNews/MilitaryOperations/RiflemanAaronLincolnKilledlnIraq.htm. 
or on the way to be, heterosexual, happy, monogamous."51 There is a tension, then: whilst obituaries attempt to humanise, they also summarise and even 'tidy up' the lives in question. Arguably, by doing this in particular ways, highlighting aspects such as sense of humour, professionalism and indeed military accomplishments, they become part of the frame that makes violence possible.

\section{Forgetting Death}

Butler is concerned that obituaries support a form of national differentiation that enables violence. She encourages us to

ask, again and again, how the obituary functions as the instrument by which grievability is publicly distributed. It is the means by which a life becomes, or fails to become, a publicly grievable life, an icon for national self-recognition, the means by which a life becomes noteworthy. As a result, we have to consider the obituary as an act of nation-building. ${ }^{52}$

This is important because the differentiation between lives effected by and reflected in the practice of having obituaries for some but not others is significant as it enables a violent reaction. In Butler's words,

we have to consider how the norm governing who will be a grievable human is circumscribed and produced in [...] acts of permissible and celebrated public grieving, how they sometimes operate in tandem with a prohibition on the public grieving of others' lives, and how this differential allocation of grief serves the derealizing aims of military violence. ${ }^{53}$

These are important points. The national frame clearly plays a part in the obituaries examined here, even beyond the fact that these lives are grievable for the UK community because they are from the UK. Rather more directly, we are told time and again that those killed on Operation TELIC have died for their country. According to his commanding officer, Private Ryan Wrathall "was eager to 'make something of his life and proud to serve the country he believed in'." "Th The family of Captain David Jones "are finding his loss very hard to bear, but take some consolation in the knowledge that he died doing the job he loved, in the service of his country." ${ }^{55}$ My concern in this piece, unlike Butler's, is not with the way in which certain lives remain unacknowledged as lives but rather with how the loss of lives that are acknowledged as such - those of Western military service personnel - come to be represented. Although to some of us soldiers' deaths may be less evocative than that of 'familiar' Danny Pearl, this is not true of those contributing to these obituaries. There is no callous disregard for these lives: they are grieved. And yet this grieving becomes part of the regulation of affect that Butler argues makes war possible. Obituaries are part of the "cultural modes of regulating affective and ethical dispositions through a selective and differential framing of violence. ${ }^{56}$

There can be no doubt that these memorials wish to acknowledge the magnitude of the loss that is entailed by the death of a person. The wife of Lance Corporal of Horse Matty Hull, killed on 28 March 2003, is explicit about what is at stake in her statement posted on the Ministry of Defence website. She says: "I have decided to issue this statement because I

\footnotetext{
$51 \quad$ Butler, Precarious Life, p. 32.

$52 \quad$ Butler, Precarious Life, p. 34.

$53 \quad$ Butler, Precarious Life, p. 37.

$54 \quad$ Ministry of Defence, "Private Ryan Wrathall dies in Basra", 13 February 2009,

http://www.mod.uk/Defencelnternet/DefenceNews/MilitaryOperations/PrivateRyanWrathallDiesInBasra.htm.

Ministry of Defence, “Captain David Jones”, 29 May 2009,

http://www.mod.uk/Defencelnternet/DefenceNews/MilitaryOperations/CaptainDavidJones.htm.

B6 $\quad$ Butler, Frames of War, p. 1.
} 
feel strongly that I should make clear that Matty wasn't just another number added to a casualty list." In order to impress her husband's singularity on us she continues to describe him as an "exceptional man". ${ }^{57}$ The singularity of the person who died - Matty Hull - is to remind us of the tragedy, the human cost. Matty Hull is not just another number, but a human being who will be missed, whose passing has a profound effect on those who loved him and may even, in Butler's terminology, 'undo' them. ${ }^{58}$

Yet these ways of remembering also reinforce ways of conceptualising violence that Butler calls the 'frames of war'. Whilst obituaries ostensibly acknowledge the individuality of the dead - describing them as "a genuine "one-off" 59 or indeed "totally irreplaceable" ${ }^{20}$ - and thereby acknowledge the human cost of war, they do not escape the discourse that makes war possible. Susan Hull, for example, notes that the respect her husband had gained amongst colleagues "makes it that much harder to accept this accidental death", but she immediately proceeds to give the 'accidental' death meaning: "Matty was fully committed to his role [...]. I know that he was where he wanted to be, doing the job he believed in when he died." 61

This idea that he was doing what he believed in or had always wanted to do is one expressed in many of the obituaries. Lieutenant James Williams, for example, "had been fascinated by aircraft" from "an early age" and "he joined the Royal Navy in fulfilment of an ambition to fly and to serve his country. His parents recall how proud he was to wear his uniform and said that he died doing the job he loved most."62 The family of Lance Corporal lan Keith Malone state that they take "some comfort from knowing that he died doing the job he loved." 63 These observations of the love of the job imply that it is a job worth loving. According to his wife, Staff Sergeant Chris Muir "died trying to do the right thing." ${ }^{\text {"C }}$ Corporal Paul Graham Long "died doing what he did best: helping others." He "wanted only to help others less fortunate than himself."

This theme of helping others sometimes finds more specific expressions. Marine Christopher Maddison's parents say that he "died in a war that will be won in his name alongside all the other brave souls who selflessly gave themselves for the freedom of all our nations." ${ }^{66}$ Sergeant Steven Roberts's wife explains that he "was adamant that he was doing the right thing and said that he was doing it for the people back home and the Iraqi people."67 Friends and family of Colour Sergeant John Cecil state that "John was proud to be a Royal Marine, proud to be British and proud to represent his country, a country dedicated into

\footnotetext{
57

Ministry of Defence, "Lance Corporal of Horse Matty Hull”, 28 May 2009,

http://www.mod.uk/Defencelnternet/DefenceNews/MilitaryOperations/LanceCorporalOfHorseMattyHull.htm.

$58 \quad$ See Butler, Precarious Life, p. 23.

59 Ministry of Defence, "Private Kevin Thompson dies in UK from injuries sustained in Iraq", 7

May 2007,

http://www.mod.uk/Defencelnternet/DefenceNews/MilitaryOperations/PrivateKevinThompsonDiesInUkFromInjuriesSustainedInlr $\frac{\text { aq.htm. }}{60}$.

Ministry of Defence, "Sergeant Steven Roberts", 28 May 2009,

http://www.mod.uk/Defencelnternet/DefenceNews/MilitaryOperations/SergeantStevenRoberts.htm.

$61 \quad$ Ministry of Defence, "Lance Corporal of Horse Matty Hull".

62 Ministry of Defence, "Lieutenant James Williams”, 28 May 2009,

http://www.mod.uk/DefenceInternet/DefenceNews/MilitaryOperations/LieutenantJamesWilliams.htm.

63 Ministry of Defence, "Lance Corporal Ian Keith Malone", 28 May 2009,

http://www.mod.uk/DefenceInternet/DefenceNews/MilitaryOperations/LanceCorporallanKeithMalone.htm.

$64 \quad$ Ministry of Defence, "Staff Sergeant Chris Muir".

65 Ministry of Defence, "Corporal Paul Graham Long”, 29 May 2009,

http://www.mod.uk/Defencelnternet/DefenceNews/MilitaryOperations/CorporalPaulGrahamLong.htm.

Ministry of Defence, "Marine Christopher Maddison”, 28 May 2009,

http://www.mod.uk/Defencelnternet/DefenceNews/MilitaryOperations/MarineChristopherMaddison.htm.

67 Ministry of Defence, "Sergeant Steven Roberts".
} 
making the world a safer place to live in."68 Rifleman Aaron Lincoln "died defending our country and bringing peace to Iraq". ${ }^{69}$ These are familiar themes of the armed forces bringing freedom, security and peace to Iraq as well as protection to the UK. What is at stake is that the deaths were not meaningless. This becomes clear in Defence Secretary Des Browne's observation on the occasion of Sergeant Jonathan Hollingsworth's death following a search and detention operation in Basra City that he "did not die in vain."

The achievements of these dead soldiers are indeed a source of pride. According to his family, Private Adam Morris "believed that he would make a difference in Iraq and was very proud to be there. He was proud to be a soldier and we are immensely proud of him."71 Rifleman Aaron Lincoln's family tell us not only that since "being a boy, all he ever wanted to do was join the Army, make his mam and dad proud", but also that he "is a hero to us all."72 Lee Fitzsimmons, according to his family, "is our hero and he is missed in a way we could never put into words." invincible we thought". ${ }^{74}$ There is, in these cases, no specific assertion as to what their heroism amounted to, other than serving in the armed forces in the first place. There are, however, those who receive special recognition for their acts at the time of their death. Lance Corporal Barry Stephen was posthumously awarded a Mention in Despatches, in recognition of the gallantry he showed in the action that also saw him killed. ${ }^{75}$ There is no information as to what Corporal Stephen did or even about how he came to die. Sergeant Mark Hudson issued a statement on behalf of the family in which he says that "both his family and I take some comfort from knowing that he died a hero, doing the job he loved." ${ }^{\prime 76}$

Whilst the families are free to call their loved ones heroes, this is not something commanding officers seem to be at liberty to do. Sergeant Eddie Collins's commanding officer comes close when he says: "He died a warrior, on the battlefield, leading from the front, doing a job he loved in the service of his friends, his regiment, his family and his country." ${ }^{\prime 7}$ Rifleman Daniel Lee Coffey has, we are told, become special by being "the first soldier of the Rifles to be killed in action". According to the commanding officer of The Second Battalion, The Rifles, "Rifleman Coffey occupies a unique place in our Regimental story. In death he is a shining example for all Riflemen who serve now and in future of what we hope to be as Riflemen. We are all proud as brother Riflemen to have served with him" ${ }^{78}$ Corporal Jeremy Brookes died "doing what he loved and in life and in the manner of his death he set us all the very highest example of service to others, courage, decency, selfsacrifice and utter commitment." It is not clear, however, from the information we are given

68 Ministry of Defence, "Colour Sergeant John Cecil RM”, 28 May 2009,

http://www.mod.uk/Defencelnternet/DefenceNews/MilitaryOperations/ColourSergeantJohnCecilRm.htm.

$69 \quad$ Ministry of Defence, "Rifleman Aaron Lincoln killed in Iraq".

70 Ministry of Defence, "Sergeant Jonathan Hollingsworth killed in Iraq", 25 November 2006,

http://www.mod.uk/Defencelnternet/DefenceNews/MilitaryOperations/SergeantJonathanHollingsworthKilledlnIraq.htm.

71 Ministry of Defence, "Private Joseva Lewaicei and Private Adam Morris killed in Iraq", 15 May

2006 ,

http://www.mod.uk/Defencelnternet/DefenceNews/MilitaryOperations/PrivateJosevaLewaiceiAndPrivateAdamMorrisKilledlnIraq. $\frac{\mathrm{htm}}{72}$.

72 Ministry of Defence, "Rifleman Aaron Lincoln killed in Iraq".

73 Ministry of Defence, "Lee Fitzsimmons killed in Iraq", 29 July 2008,

http://www.mod.uk/Defencelnternet/DefenceNews/MilitaryOperations/LeeFitzsimmonsKilledlnIraq.htm.

${ }_{74}$ Ministry of Defence, "British Officer killed in Iraq - Major Matthew Bacon”, 11 September 2005, http://www.mod.uk/Defencelnternet/DefenceNews/MilitaryOperations/BritishOfficerKilledlnIraqMajorMatthewBacon.htm.

75 The London Gazette, 31 October 2003, Supplement no. 1, p. 6, http://www.london-

gazette.co.uk/issues/57100/supplements/6.

$76 \quad$ Ministry of Defence, “Lance Corporal Barry Stephen”, 28 May 2009,

http://www.mod.uk/Defencelnternet/DefenceNews/MilitaryOperations/LanceCorporalBarryStephen.htm.

${ }_{77} \quad$ Ministry of Defence, "Sergeant Eddie Collins killed in Iraq", 8 September 2007,

http://www.mod.uk/Defencelnternet/DefenceNews/MilitaryOperations/SergeantEddieCollinsKilledlnIraq.htm.

${ }_{78}$ Ministry of Defence, "Rifleman Daniel Lee Coffey killed in Iraq", 28 February 2007,

http://www.mod.uk/Defencelnternet/DefenceNews/MilitaryOperations/RiflemanDanielLeeCoffeyKilledlnIraq.htm. 
what exactly the 'manner of his death' was. All we are told is that he "died as a result of injuries sustained from a small arms fire attack on his patrol in Basra City". ${ }^{79}$ It is rare, in fact, that we learn much about the death itself. That Leading Aircraftman Martin Beard "fell, weapon in hand, fighting for and alongside his comrades" is an unusually dramatic account. ${ }^{80}$

Usually, the description of the death is bland. Lance Corporal of Horse Matty Hull died in what was believed "may have been a 'friendly fire' incident". ${ }^{1}$ Guardsman Anthony Wakefield died "as a result of wounds sustained during a routine patrol in Al Amarah, Iraq." Staff Sergeant Chris Muir was killed "during an explosive ordnance disposal operation in southern Iraq". ${ }^{83}$ Sometimes there is more of a story about the operation that led to death. Corporal Rodney Wilson, for example, was part of a search and detention mission north west of Basra City when his patrol came under attack from small arms fire and rocket propelled grenades. Corporal Wilson was hit during his attempt to evacuate one of the wounded. He was taken to the field hospital by helicopter but "despite receiving the best possible treatment, he died of his injuries at 0340 hours." ${ }^{\text {B }}$ By and large we learn little about how death occurred. In an unusually graphic description, we are told that Sergeant Graham Hesketh "was killed in action while patrolling in Iraq by a kerbside bomb exploding under his Jeep," ${ }^{85}$ though what this means is left to our imagination. Often the language is technical to the point of being sanitised. Lieutenant Richard Palmer was killed when the vehicle he was commanding "was contacted by a roadside bomb." ${ }^{\prime 6}$ In particular, we learn little about the deaths that cannot easily be classified as 'in action' or at least 'by accident'. Private Ryan Wrathall was the last to die before Operation TELIC officially ended: he "was found at Basra's Contingency Operating Base having suffered a gunshot wound" and "[n]o enemy forces were involved and there is no evidence to suggest that anyone else was involved." 87 Private Wrathall is by no means the only one to have died from gunshot wounds on base. ${ }^{88}$ More generally, of the 179 killed on operation TELIC, "43 are known to have died either as a result of illness, non-combat injuries or accidents, or have not yet officially been assigned a cause of death pending the outcome of an investigation." 89

One might argue that death is hidden in plain sight in these obituaries. Whilst we are certainly told of the death, this is done in technical language not conducive to making us picture the horror of the death. These obituaries largely celebrate the lives that are lost.

79 Ministry of Defence, "Corporal Jeremy Brookes from $4^{\text {th }}$ Battalion The Rifles killed in Iraq", 22 May 2007,

http://www.mod.uk/Defencelnternet/DefenceNews/MilitaryOperations/CorporalJeremyBrookesFrom4thBattalionTheRiflesKilledln Iraq.htm.

$80 \quad$ Ministry of Defence, "Leading Aircraftman Martin Beard Royal Air Force Regiment killed in Iraq", 9 August 2007,

http://www.mod.uk/Defencelnternet/DefenceNews/MilitaryOperations/LeadingAircraftmanMartinBeardRoyalAirForceRegimentKil ledInIraq.htm.

$81 \quad$ Ministry of Defence, "Lance Corporal of Horse Matty Hull".

82 Ministry of Defence, "Death of Guardsman Anthony Wakefield in Iraq", 2 May 2005,

http://www.mod.uk/Defencelnternet/DefenceNews/MilitaryOperations/DeathOfGuardsmanAnthonyWakefieldlnlraq.htm.

${ }_{83} \quad$ Ministry of Defence, "Staff Sergeant Chris Muir".

84 Ministry of Defence, "Corporal Rodney Wilson killed in Iraq", 8 June 2007,

http://www.mod.uk/Defencelnternet/DefenceNews/MilitaryOperations/CorporalRodneyWilsonKilledlnIraq.htm.

${ }_{85} \quad$ Ministry of Defence, "Sergeant Graham Hesketh killed in Iraq", 29 December 2006,

http://www.mod.uk/Defencelnternet/DefenceNews/MilitaryOperations/SergeantGrahamHeskethKilledlnIraq.htm.

April 2006,

Ministry of Defence, "Lt Richard Palmer of The Royal Scots Dragoon Guards killed in Iraq", 16

http://www.mod.uk/Defencelnternet/DefenceNews/MilitaryOperations/LtRichardPalmerOfTheRoyalScotsDragoonGuardsKilledlnl raq.htm.

Ministry of Defence, "Private Ryan Wrathall dies in Basra".

88 Ministry of Defence, "Staff Sergeant Denise Rose", 29 May 2009,

http://www.mod.uk/Defencelnternet/DefenceNews/MilitaryOperations/StaffSergeantDeniseRose.htm; Ministry of Defence,

"Sergeant Paul Connolly", 29 May 2009,

http://www.mod.uk/Defencelnternet/DefenceNews/MilitaryOperations/SergeantPaulConnolly.htm.

${ }_{89} \quad$ Ministry of Defence, "Operations in Iraq: British Fatalities". 
They do not dwell on the dying, do not tell us how exactly someone died, unless perhaps some specific act of bravery may be reported. We in general give little thought to how people actually die in war and I have written about this elsewhere. ${ }^{90}$ What is intriguing is not just that the death itself is almost left to one side. This, surely, is understandable in the context, precisely, of grief. It is rather how soldiering is represented in these obituaries. Soldiering is a career, marked not so much by violence and death, as by professionalism. Sergeant John Jones "was a dedicated and consummate professional, who hated tardiness, was physically fit and had a keen eye for detail. Always willing to lead by example, he was never afraid to get his hands dirty and set high standards for himself and those whom he commanded, but he was always fair, just and compassionate." ${ }^{\prime 1}$ Lance Corporal David Kenneth Wilson "embodied exactly what is best about soldiers in the British Army; he was a jolly, friendly and selfless character who was wholly respected by his peers and friends alike", ${ }^{92}$ whilst Lance Corporal Paul Farrelly "embodied much of what is best about soldiers in the British Army; selfless, determined, humorous and steadfast in the face of adversity." Apart from embodying a professionalism that seems to make more reference to a sense of humour than it does to the eventuality of having to kill people, there is much reference to the qualities of being caring and gentle. Corporal Christopher Read was marked out by his "sheer gentleness", for example. Indeed, according to Corporal James McIntyre, he "was a gentle giant, who would never have hurt a fly and would always do anything for anyone." Violence does not seem to be part of this frame and therefore Secretary of State for Defence John Reid can refer to an attack on UK armed forces in Iraq as an 'appalling act of violence', as though this is inexplicable behaviour on the part of the Iraqis. As he put it on the occasion of the death of Major Matthew Bacon, killed whilst on patrol in Basra City: "As always, my thoughts are with the family and with the families of those injured in this appalling act of violence." 95

This erasure of violence makes death, when it comes, a tragedy. The obituaries confront us with the "tragic" loss of young lives, such as the death of 19-year old Trooper David Clarke, killed in a so-called 'friendly fire incident', which is described by his commanding officer as "a tragic loss of a young man who had a promising career ahead of him." 96 Private Michael Tench's death, equally, is "a tragedy" because "we have lost a young man with so much promise." It is not just the life already lived that is wiped out and lost; it is rather the future that becomes impossible. Private Adam Morris "undoubtedly had a bright future ahead of him"98 and this makes the loss all the more terrible. But these tragedies are tragedies in the sense of always having been in store, not in the sense of randomness,

\footnotetext{
90 On the erasure of ways of dying see Zehfuss, Wounds of Memory, esp. chapters 3 and 6.

91 Ministry of Defence, "Sergeant John Jones killed in Basra", 21 November 2005,

http://www.mod.uk/Defencelnternet/DefenceNews/MilitaryOperations/SergeantJohnJonesKilledInBasra.htm.

92 Ministry of Defence, "Lance Corporal David Kenneth Wilson dies in Iraq", 5 December 2008,

http://www.mod.uk/DefenceInternet/DefenceNews/MilitaryOperations/LanceCorporalDavidKennethWilsonDiesInlraq.htm.

Ministry of Defence, "Lieutenant Tom Mildinhall and Lance Corporal Paul Farrelly in Iraq", 30

May 2006,

http://www.mod.uk/DefenceInternet/DefenceNews/MilitaryOperations/LieutenantTomMildinhallAndLanceCorporalPaulFarrellyKill edlnIraq.htm.

$94 \quad$ Ministry of Defence, "Corporal Christopher Read $3^{\text {rd }}$ Regiment Royal Military Police in Iraq", 9 July 2007 ,

http://www.mod.uk/Defencelnternet/DefenceNews/MilitaryOperations/CorporalChristopherRead3rdRegimentRoyalMilitaryPolice KilledInIraq.htm.

95 Ministry of Defence, "British Officer killed in Iraq - Major Matthew Bacon".

96 Ministry of Defence, "Trooper David Clarke", 28 May 2009,

http://www.mod.uk/DefenceInternet/DefenceNews/MilitaryOperations/TrooperDavidClarke.htm. See also Ministry of Defence, "Lance Corporal of Horse Matty Hull”; Ministry of Defence, "Colour Sergeant John Cecil RM". 97 Ministry of Defence, "Private Michael Tench killed in Basrah City, Iraq", 22 January 2007, http://www.mod.uk/Defencelnternet/DefenceNews/MilitaryOperations/PrivateMichaelTenchKilledlnBasrahCitylraq.htm. 98 Ministry of Defence, "Private Joseva Lewaicei and Private Adam Morris killed in Iraq".
} 
unexpectedness. Much like Oedipus could not, much as he tried, avoid killing his father, armed forces personnel will die in war. ${ }^{99}$

Part of the possibility of accepting soldiers' deaths despite their humanity indeed seems to hang on the idea that they are not random and in some sense not tragic; for unlike civilians who are caught up in warfare unwillingly, soldiers are seen to have made a choice. According to Lance Sergeant Lyttle Lance Corporal Kirk Redpath "laid down his life" and he "would have done it so willingly." 100 Lieutenant Richard Palmer "was very well aware of the dangers that he and others faced in Iraq, but he believed that the work they were doing was gradually making life better for the Iraqi people."101 But there is also a certain trivialisation or perhaps rationalisation of the risk. This is particularly obvious in the statement by Major Matthew Bacon's parents who say that they thought their son was "invincible", as he had served "in conflict zones including Northern Ireland, the Gulf, Former Yugoslavia and Afghanistan" and also enjoyed "high-risk sports like sky-diving". They carry on to say that they "always understood the risks attached to Matthew's career but never imagined that anything could or would happen to [their] son."102 This sentiment is understandable, but it rather suggests that death, and its possibility, had been forgotten.

\section{Conclusion}

Members of the armed forces are recognised as having lives that are grievable. Based on the hierarchy of grief, their lives should be highly protected. They are Westerners and their deaths receive the kind of attention that suggests that their lives are indeed taken seriously as lives. Examining the obituaries has confirmed this. They show military personnel as human beings with families, careers and hopes for the future. They show them as having a sense of humour and often their own foibles. These obituaries confirm Butler's assertion that Western lives are grievable. They also confirm, though much more indirectly, Butler's concern that non-Western lives are not acknowledged as lives. The UK armed forces are portrayed as consummate professionals working hard to help and to bring peace, who are gentle and caring and indeed in one case could 'never hurt a fly'. The violence that is an inevitable part of the military profession is erased from these obituaries and this surely relies on what Butler so powerfully draws to our attention: the understanding of the lives that Western forces end as lives that cannot be grieved, as lives that are not really lives. This differentiation makes it appear as though Western armed forces do not kill, but are killed. This differentiation therefore makes possible the pride in these soldiers' service and underlines the grief at their 'tragic' deaths. The frame of Western lives versus non-Western non-lives is revealed not only in who gets an obituary and who does not, but also in how the Western lives in the obituaries are construed.

Butler's 'frames of war' permeate these obituaries. Yet whilst this confirms her argument to an extent, she does not consider the peculiar situation of the armed forces and therefore has nothing to say about how it is that we are, despite their grievability, prepared to risk their lives. In other words, whilst the issue of grief (and indeed the lack of it) raises some very powerful questions, especially about war between the West and the non-West, grief seems to do less well in terms of providing a resolution to the problem of violence. If we are prepared to accept the deaths of military personnel whom we grieve, then our failure to grieve non-Western lives may well be indicative of our inability to recognise and cherish their

$99 \quad$ I discuss how ideas of accident and inevitability come together in the notion of tragedy in "The Tragedy of Violent Justice: The Danger of Elshtain's Just War Against Terror", International Relations, vol. 21, no. 4 (2007), p. 498.

$100 \quad$ Ministry of Defence, "Lance Sergeant Chris Casey and Lance Corporal Kirk Redpath killed in Iraq", 10 August 2007,

http://www.mod.uk/Defencelnternet/DefenceNews/MilitaryOperations/LanceSergeantChrisCaseyAndLanceCorporalKirkRedpath KilledInIraq.htm.

$101 \quad$ Ministry of Defence, "Lt Richard Palmer of The Royal Scots Dragoon Guards killed in Iraq".

102 Ministry of Defence, "British Officer killed in Iraq - Major Matthew Bacon". 
lives enough, but there is little evidence to suggest that the reverse might be true: that if we recognised non-Western lives as lives, violence against people in the non-West would become impossible.

That is, grief ultimately does not seem to be enough to stop violence. This indeed seems to be what Butler is wrestling with; for she challenges us to find a way to translate the recognition of grievability into a critique of war:

We read about lives lost and are often given the numbers, but these stories are repeated every day, and the repetition appears endless, irremediable. And so, we have to ask, what would it take not only to apprehend the precarious character of lives lost in war, but to have that apprehension coincide with an ethical and political opposition to the losses war entails? Among the questions that follow from this situation are: How is affect produced by the structure of the frame? And what is the relation of affect to ethical and political judgment and practice? ${ }^{103}$

Although it is difficult to do justice to Butler's reflections on what it means to be human here, she seems to suggest that the recognition of lives as lives will make us more inclined towards non-violence. She acknowledges that there is no easy necessity here, ${ }^{104}$ but she does argue that the "critique of violence must begin with the question of the representability of life itself: what allows a life to become visible in its precariousness and its need for shelter, and what is it that keeps us from seeing or understanding certain lives in this way?"105 She wants us to think about how our affective and ethical dispositions are regulated "through a selective and differential framing of violence."106 The affective dispositions towards members of the armed forces shown by and produced in the obituaries examined here are clearly regulated in this way. The pride at the soldiers' accomplishments relies on valuing professionalism as well as on discounting the fact that they kill. They rely on the differentiation of grievability that Butler identifies.

Yet the lives of the UK service personnel occupy a space she does not account for: these are lives and we recognise them as such, and yet these lives may be risked (and therefore killed) as a matter of course. The grief of family, friends and colleagues does not stop us nor does the performance of mourning by the armed forces and the Secretary of State for Defence. Whilst we do not see grief translated into a cry for war, there also does not seem to be evidence that grief, as expressed and enacted in these obituaries, has encouraged a critique of war. Some grieving families have, of course, set up groups protesting against the war in Iraq, but this is difficult. The obituaries show that the frame that makes sense of war asserts itself within grief. The lives were not given in vain: they were given out of professional commitment, to help others, for security. The pain of loss would be unbearable is the death had been senseless.

The new Elizabeth Cross awarded to the families of UK military service personnel killed on operations since the Second World War is interesting in this regard. ${ }^{107}$ It is not awarded in recognition of gallantry or bravery, but merely for having died whilst on a military operation. In other words, what is central is the grief and suffering caused to the families rather than any accomplishment of the one who has been killed. It makes sense of the death without requiring anything else. This is, in keeping perhaps with our times, not an award for heroes, but an award for persons loved just for being who they were (and, of course, being on a military operation at the time of their death). Indeed, the award is explicitly to honour the families rather than the dead. Obituaries, similarly, are in an important sense not about the

\footnotetext{
$103 \quad$ Butler, Frames of War, p.13.

104 Butler, Frames of War, chapter 5.

$105 \quad$ Butler, Frames of War, 51.

106 Butler, Frames of War, p. 1.

107 Ministry of Defence, "Elizabeth Cross honours families of fallen troops", 1 July 2009 ,

http://www.mod.uk/DefenceInternet/DefenceNews/HistoryAndHonour/ElizabethCrossHonoursFamiliesOfFallenTroops.htm.
} 
dead. Despite our concern about what we may owe the dead, they are dead and hence in no position to be affected by our memorial practices. Mourning is for those left behind, though it is more complicated as grief - and Butler powerfully shows this - precisely indicates the inseparability of human beings from one another.

Speaking of the dead and our relations with them is beset by dangers: the danger of bad taste, of instrumentalisation, of inventing meaning. ${ }^{108}$ Obituaries retrospectively create lives that will never have been in quite this way. ${ }^{109}$ There is indeed something awkward about the individualisation, the humanising that marks these obituaries: they seem to attempt to make armed forces personnel into persons after death. Of course, they were persons to their families and friends all along, but in life and indeed in their death they were also claimed as military service personnel, and therefore as life that is, though grievable, treated as (more) expendable. This is a tension that informs Butler's questions: the impossible relationship between the use of a life in the pursuit of military violence and the inevitable despair when this life is lost, between our functionality in a social context and our singularity, between the inescapable desire to assign meaning to death and the despair at its utter senselessness. With her notion of grievability, Butler has found a powerful way of raising this issue, but in not considering the lives of Western service personnel who are grievable and yet not given the sort of protection that other Western lives may expect, Butler misses an opportunity. These obituaries reveal no cry for war and yet neither do they seem to offer the other way forward that Butler is seeking. The despair at the loss of an irreplaceable life does not necessarily predispose us to question the frames that make violence and war possible, as the frame inevitably always already frames the loss. But it may be the negotiation between these two the way in which both the frame and the recognition of singularity inevitably fail - that could offer us the best chance to find the resources to re-imagine the frame we cannot escape.

\footnotetext{
108 See Derrida, The Work of Mourning.

109 For my argument that memory retrospectively produces a past while claiming merely to invoke it see Wounds of Memory.
} 